\title{
Thinking like a student: subject guides in small academic libraries
}

\author{
Catherine E Kerrigan
}

Librarian, Adelaide Central School of Art

This is an Accepted Manuscript of an article published by Taylor \& Francis in Journal of Web Librarianship on 15 July 2016, available online:

\section{http://www.tandfonline.com10.1080/19322909.2016.1198743}

\section{Abstract}

Small academic libraries still need to produce web-based subject guides despite limited budgets. This practical communication describes how one such library in Australia used freely available wiki software and third-party hosting to create a web-based set of subject guides and a subsequent redesign based around typical student tasks. It demonstrates that it is possible to produce high quality guides that meet student needs with minimal costs.

Keywords

Academic libraries, Subject guides, Students, Wikis

\section{Thinking like a student: subject guides for small academic libraries}

\section{Introduction}

Subject guides are a common feature of academic library websites and are commonly intended to assist users in finding what they need in an academic collection. LibGuides is a commonly used commercial software application for creating guides (SpringShare 2013). However, LibGuides is not a viable option for academic libraries with small budgets. This practical communication describes how one academic library created a web-based subject 
guide using a free wiki-hosting website and a subsequent redesign of the wiki to improve its usability for students.

\section{Background information}

Australia has a well-established and active higher education sector which is split between universities and non-university higher education providers (NUHEPs), with 43 universities and 129 NUHEPs (Norton and Cherastidtham 2014, 9). NUHEPs include TAFEs (Tertiary and Further Education institutions) which are publicly funded and the nearest Australian equivalent to North American community colleges, and private higher education providers which usually focus on a single discipline such as theology, business, and design. However, although independent institutions outnumber the public institutions by three to one, student numbers show that universities dominate the sector. According to the Department of Education and Training (2015), 1.025 million domestic students were enrolled in higher education institutions in 2014. Of these, the Grattan Institute estimates that 54,000 FTE (fulltime equivalent) students were enrolled in NUHEPs in 2013 (Norton and Cherastidtham 2014, 11).

With respect to libraries, web librarianship in Australia is fairly advanced, however this is largely dependent on the library involved. Trove (http://trove.nla.gov.au/) is Australia’s flagship library website and functions as a discovery layer, metadata aggregator and digital portal to Australian collections (National Library of Australia 2016a). It has been described as an essential part of Australian research infrastructure and is credited with transforming humanities research in Australia (Jones and Verhoeven 2016; The Australian Academy of the Humanities 2016). It serves as an example of what a national digital library can be. However, the Australian Library and Information Association (ALIA) has noted that libraries' online presence “tend to be purely functional” even though “they will need to look as good online as they do in the real world” (Australian Library and Information Association 
2014, 28). My own review of academic websites indicates that this is particularly true of private NUHEPs, many of whom do not even have a web presence (see below).

With respect to training for web librarianship, ALIA provides many workshops and courses each year for librarians to develop their digital and online skills. The wiki workshop that introduced me to wiki software was run by ALIA. Digital skills also featured heavily in the master's degree that I undertook at the University of South Australia.

The Adelaide Central School of Art (the School) as an independent and not-for-profit institution is one of the smaller NUHEPs. The School, whose library is the focus of this article, is one of only three art schools in South Australia (the others being the School of Art, Architecture and Design at the University of South Australia and the Adelaide College of the Arts at TAFE SA) and one of only two independent art schools in Australia (the other being the National Art School in Sydney, New South Wales). Founded in 1982, the school is fully accredited by the Tertiary Education Quality and Standards Agency, which ensures adherence to the Australian Government’s requirements for the higher education sector.

The School offers a structured four-year course in visual arts with exit points leading to an Associate Degree in Visual Arts (two years), a Bachelor of Visual Arts (three years) and a Bachelor of Visual Art (Honours) after four years. Entry to the fourth year is not automatic: outstanding students are invited to join the Honours year after graduating with the three-year Bachelor of Visual Arts. Although the School is independent, students can access government-funded student loans via the Australian FEE-HELP system. The School has approximately 28 part-time faculty and 192 students (FTE 90 students) ranging in age from 18 to 67. Of these, 79 students were in enrolled in art history subjects in 2015.

Shortly after commencing my MLIS studies in 2010, I began volunteering in the School's library. Due to its size, the School did not have a librarian and the School's library 
was very small and rather neglected. The collection of almost 2,500 books had been developed primarily through donation and existed as a reference collection in an unsupervised room, which it shared with three computers and a printer set aside for the students. The library’s catalogue was a DOS-based program developed for use in South Australia's government schools and was only available on the three student computers. The School was grateful to have a student librarian volunteer to work in its library, because it was otherwise managed by the School's administrative staff, who had little time to devote to it.

The School also did not have a formal library budget - its only financial commitment to the library in 2010 were subscriptions to six Australian print art journals and Grove Art Online (now Oxford Art Online) (Oxford University Press 2015). Although art library collections continue to be predominantly print-based, art students still need access to online academic databases, particularly journal databases such as JSTOR (ITHAKA 2015). Fortunately as an Australian school, students and faculty are able to access some of the more popular databases through membership of the National Library of Australia (NLA), and the School actively encourages this. Australian residents can join the NLA for free and access its e-resources via the NLA’s website and their membership number (National Library of Australia 2015b). The School also encourages students to join one of the university libraries in Adelaide, as community borrowers (individuals who are not student, staff or alumni of the universities), with the School either partially or fully reimbursing the membership fees.

Among the many issues I faced in bringing the library up-to-date were a pair of related questions: how to supplement the small library collection with high-quality and freely available web resources, such as those available through the world's leading art galleries and museums and those available through the NLA, and how to inform students of these resources. As noted in the introduction, LibGuides was not an option due to budgetary limitations. So, when an opportunity arose to learn how to use wiki software through the 
Australian Library and Information Association (ALIA), I took it in the hope that I could then use the wiki software to create a subject guide for the School's students.

\section{Wikis and subject guides}

Wiki software has been well promoted by librarians as a good option for libraries seeking to develop and implement subject guides. Farkas (2007, 33), Yang (2009, 96), and Tripathi and Kumar (2010, 204) have all recommended wikis for this purpose. A review of the literature suggests that libraries have indeed used wikis for this purpose but are now transitioning away from wikis to LibGuides. Bejune in a 2007 survey of 33 library wikis found three libraries using them for this purpose (Bejune 2007, 31). However, since then, all three have been discontinued or replaced by other software (Boeninger 2011). Woody (2015, 1-12) describes a case study of a multi-site hospital library that migrated from freely-hosted wiki software for the library website to LibGuides CMS. Surveying use of Web 2.0 tools in 120 public and academic libraries, Chua and Goh found that wikis were only used in ten of those libraries, primarily for collecting subject-matter related material $(2010,208)$. A survey of 82 African university libraries found that they lagged behind their international counterparts in the use of Web 2.0 tools and fewer than ten libraries used wikis and did not indicate what they were used for (Wordofa 2014, 275). In an Australasian context, a scan of university library websites found no external evidence of wiki use (Nguyen 2008, 642). Boateng and Yu's survey of the top 100 US academic libraries found that the wiki was the least used Web 2.0 tool, with only 34 libraries using wikis and 22 using them for resource listings $(2014,130)$. They also noted that wikis allow for easy and seamless "creation, editing and collaboration” (Boateng and Quan Liu 2014, 130). My own scan of Australian academic library websites indicated that the majority of public university libraries use LibGuides. The same scan showed that, with respect to NUHEP websites, either they did not provide subject guides (38 institutions), used a mix of software packages (21), or the library 
pages were on an intranet and so the status of any subject guides could not be determined (19). Clearly there is scope to conduct further research to understand why such a large proportion of NUHEPs do not provide subject guides. From this scan, it appears that the Adelaide Central School of Art is the only Australian higher education institution using a wiki for providing subject guides.

Much of the literature has focused on the development of subject guides and not so much on the intended users of those guides. Cornell University librarians discovered that users searched for subject guides primarily through a known reference such as a course code, name of the guide or the librarian's name, suggesting that Cornell's subject guides should be more tightly linked to courses (Castro Gessner, Chandler, and Wilcox 2015, 501). They also found a mismatch between what the librarians and users felt was the best placement of the most important content: Cornell's librarians tended to place it on the second tab of the Libguide where users looked for it on the home page (Castro Gessner, Chandler, and Wilcox 2015, 500). A Canadian study found that users didn’t just want to be pointed to a resource: they looked for guidance on how to use it, which suggested to the librarians that more instructional content should be embedded within the guides (Hintz et al. 2010, 46). Hintz et al. also found that design was an important consideration with users preferring a clean and simple layout (2010, 45). This preference was confirmed by another Canadian study which also found that library jargon and the tabs that are a feature of the LibGuides software were confusing to users (Ouellelte 2011, 445-6).

\section{Libguides vs Wikispaces}

In many respects, Libguides and Wikispaces are very similar in that they are both fully hosted services, aim to be easy to learn and use, and are browser-based for ease of access and editing. Libguides is also easier to integrate into an institution's website through the use of custom domain names (Richards 2014). This can also be done in Wikispaces but 
there is usually a delay of 24 hours before this occurs (Wikispaces 2014). Libguides uses a tab-based structure which some users have found confusing (Ouellelte 2011, 445-6). Wikispaces uses a page structure which is typical of wiki software and familiar to users of wikis such as Wikipedia. Not having used Libguides, I cannot comment on the ease of use, however, I have found Wikispaces to be easy to use. The major advantage Wikispaces has over Libguides is that it is free to use.

\section{The School's wiki}

When I first set out to develop the wiki, the wiki software used was Wikispaces (https://www.wikispaces.com/), which also hosts wikis with options for free and paid hosting (Tangient LLC 2015a). Although there are other free wiki-hosting services available, the advice at the workshop I attended was that Wikispaces was one of the better platforms and it was the software taught at that workshop. Since attending this workshop, Wikispaces has introduced an educational subscription. Wikis created specifically for educational purposes have additional features such as projects and the ability to assign members of the wiki to specific project teams (Tangient LLC 2015b). Educational wikis are free to create and are free of advertising, although there are paid subscription options for larger institutions: these subscriptions provide dedicated wiki environments, allowing for closer integration with the institution’s own systems (Tangient LLC 2015b; Tangient LLC 2015c). I found Wikispaces a very easy software package to learn and use. Accordingly, I used it to create the School's Library Online Resources wiki and it was set as the homepage on the student computers in the School (Adelaide Central School of Art 2015). Early versions of the homepage were very basic, as can be seen in Figure 1. 


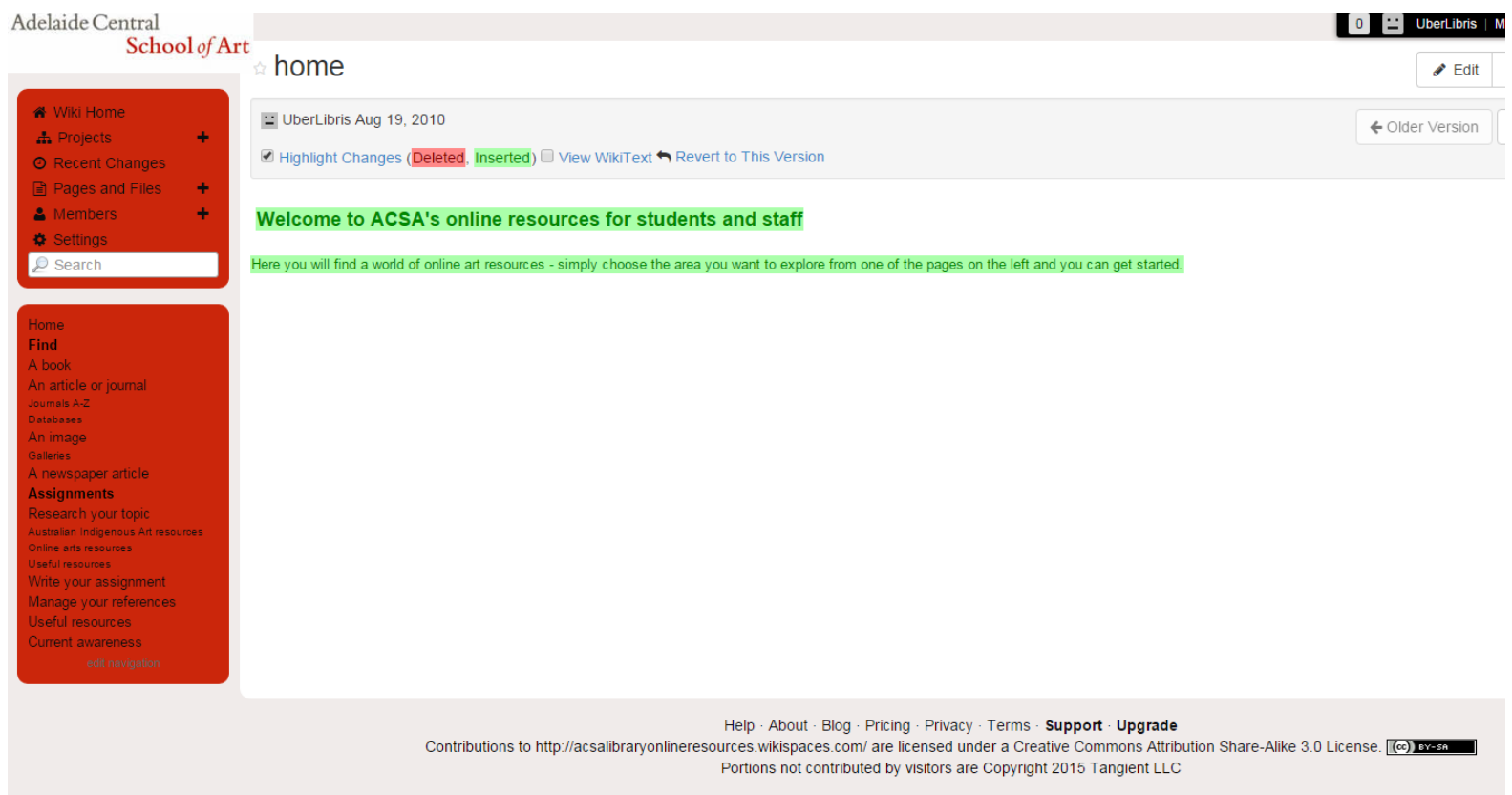

Figure 1 Original home page

The wiki itself consisted of pages devoted to resource types such as arts journals, databases, and art galleries and museums, rather than subjects such as painting, drawing, or sculpture. My reasoning for this was that, when I looked at subject guides on other academic library websites such as the University of South Australia and other universities with art schools, they tended to be resource-focused in broad subject areas such as visual arts, or taskfocused such as searching, writing, and citing sources. The subject guides on other academic library websites also tended to focus on their own collections rather than material outside their collections, though generally there would be a tab on each guide listing web resources. Because the aim of the wiki was to supplement the School's collection with high quality and freely available online resources, and given that the School is a single discipline school, the focus of the wiki was on resource type, rather than subject or task. An example of this was the galleries page (see figure 2). 

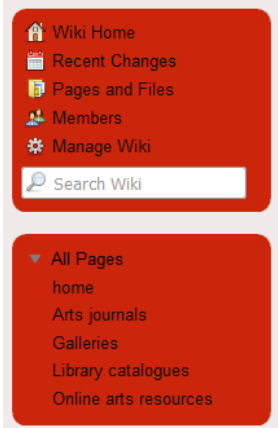

\section{Galleries}

Many galleries now have online exhibitions or other digital resources.

Adelaide galleries

Art Gallery of South Australia 2

Aft Images Gallery

At Logic מ

Better World Arts

BMG Att

Feltspace

Flinders University City Gallery

Greenaway Art Gallery

Greenhill Galleries Adelaide w

HIII Smith Gallery

Hugo Michell Gallery

Anne and Gordon Samstag Museum of Ait

Tandanya

The Jam Factory

Figure 2 Galleries page

Around these resource types, the wiki provided links to the NLA, Oxford Art Online, museums such as the National Gallery of Australia, the Museum of Modern Art (MOMA), and the Tate Gallery, and Trove. The wiki gave a small amount of advice on searching and where to find specific art journals online. Conversations with members of the art history department revealed their enthusiasm for the wiki, but it was the product of a librarian who was an experienced web searcher. A small amount of feedback from students was positive but overall, I was left feeling that there was considerable scope to improve it and make it more usable for the students.

\section{The redesign of the wiki}

In 2014, after a redesign of the information literacy classes that I taught at the Adelaide Central School of Art, I conducted an analysis of the bibliographies from student assignments. The results were pleasing - at least three-quarters of the sources used by students were academic sources (Kerrigan 2014). However, there was still room for 
improvement, and in conjunction with reference questions I received in the library, the analysis indicated that students still had difficulty in formulating search phrases and knowing where to start their research.

Having already redesigned the information literacy classes to more specifically target the skills and sources the students needed at each level of their degrees, I sat down to redesign the wiki over the Australian summer vacation in 2014-2015 (http://acsalibraryonlineresources.wikispaces.com/).

The redesign structured the pages around two key tasks that students undertake: finding information for their assignments, and writing their assignments. To support the task of finding information, I added four pages - one each for the tasks of finding a book, a journal article, a newspaper article, and an image. Some of the existing pages were then grouped under those task headings; and links to the School's catalog, Trove, and the NLA were moved to appropriate pages (e.g. on the page "Find a book"). To support the task of writing assignments, five new pages were added - three for the tasks of researching an assignment, writing an assignment, and managing references, with two additional pages about useful resources and current awareness. The remaining pages were moved to appropriate places under those tasks and material from the information literacy classes such as how to develop a search phrase and search strategies was included. Additional material was added such as links to online glossaries of art terms from MOMA and the Tate (MoMALearning 2015; Tate Gallery 2015). The home page was also laid out more graphically with greater use of icons and images, and a manually created navigation bar was substituted for the automatically generated navigation widget (see Figure 3). 


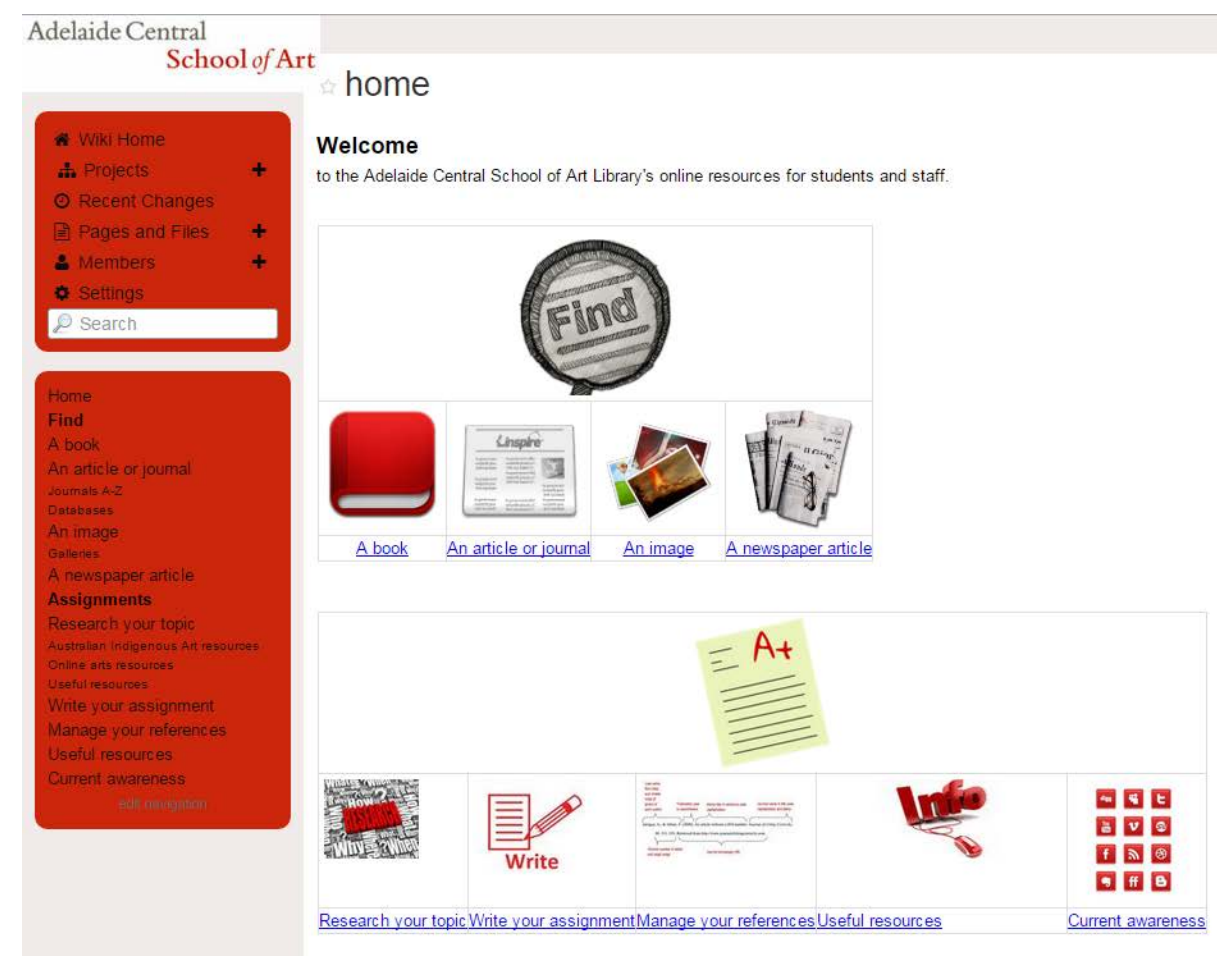

Figure 3 Current home page

Response to the redesign

Feedback was sought from art history faculty and Student Support colleagues via a simple email request asking them to review the revamped wiki, and it was enthusiastic and consistent: I was repeatedly told that I was now thinking like a student. This consistent feedback suggested that I was on the right track. To promote the wiki, its URL was included in the School’s Essay Writing Guide

\section{(http://www.acsa.sa.edu.au/fileadmin/public/pdfs/2015_Essay_Writing_Guide.pdf) and}

printed on a library bookmark which is handed out in class and in the library. The art history faculty also promote its use to students and a link to the wiki is included on the School's website under Student Resources/Library.

At this stage, there has been little or no feedback from the students. This could either mean that they do not use the wiki or at all or that they are very comfortable with using it and so do not seek out any help from their librarian. However, checking the statistics on the 
wiki's internal dashboard has yielded some interesting results. Use of the wiki doubled following its redesign. In 2014, the total page views (excluding the home page) was 516. In 2015, the total page views to mid-November (again excluding the home page) was 1,175 . In 2014, the four most popular pages were Galleries (82 views), Arts Journals (76 views), Library Catalogs (70 views) and Australian Indigenous Art (69 views). In contrast, the four most popular pages in 2015 were Research your topic (113 views), Find an article or journal (111 views), Find an image (104 views), and Manage your references (90 views). This doubling of use and change in most popular pages suggests that the redesign - changing the focus of the wiki from resource type to student task - has been more successful at meeting student needs than the original wiki.

However, there is a caveat: only $50 \%$ of the hits on the wiki came from Australian IP addresses $-40 \%$ came from the US and the remaining $10 \%$ from other countries. Accordingly, the numbers given above are half of the actual page views. Furthermore, the wiki’s dashboard includes a disclaimer that it cannot distinguish searchbots in its results.

Therefore the next stage is to employ web analytics software such as Google Analytics so that usage can be more accurately tracked (Google 2015). The wiki has a feature that enables Google Analytics to be used as a plug-in to facilitate this and this was installed over the 2015-16 summer break. This could be followed up with inclusion of a question regarding the wiki in the annual student satisfaction survey that the School conducts. Nonetheless, the increased use indicates that embedding further instructional material in the wiki would be helpful to students and this is consistent with the findings of user studies conducted in the US and Canada (Castro Gessner, Chandler, and Wilcox 2015, 500; Hintz et al. 2010, 46). 
Developing the wiki has been a learning curve that has accompanied my own development as a librarian and more importantly accompanied my developing understanding of the needs of the School's students. I mentioned above that the decision to refocus the wiki on student task rather than resource type arose out of the evaluation of the information literacy training I conduct for the School. That evaluation followed a restructure of the information literacy training that aimed to target the training more specifically to student development, rather than take a one-size-fits-all approach, as I had done in the first two years. In restructuring the information literacy training, I worked closely with faculty to determine the students' needs and skill levels and identify the most appropriate material and techniques to include at each year of the degree.

Had I worked more closely with the faculty when I began work on the wiki, I may well have focused it on student task rather resource type. The initial need appeared to be supplementing the School's resources. That need still exists, however the types of resources needed are determined by the students' needs which are task-oriented. The wiki's content would then have been shaped by those needs. One thing I should have done was ask the faculty for feedback on the wiki's structure and content when I first developed it and whenever I updated it. However, I only did that after the major redesign and, in future, will seek their feedback whenever any major changes are made to the wiki, such as adding a new page.

Evaluation is always an issue and, although the wiki’s dashboard provides some statistics on usage, its inability to exclude searchbot results is problematic. Also, user location is only by country and is therefore not sufficiently fine-grained to understand the implications of users from the United States and the rest of the world visiting the wiki. I should therefore have used Google Analytics from the start. 


\section{Conclusion}

In 2015, the Adelaide Central School of Art’s library has developed considerably from where it was in 2010. I was formally appointed the School's librarian in 2011 and, although I am part-time, I am assisted by two volunteers who open the library when I am not there and most of the School's staff have received training from me on the library's catalog (the open source Koha) and RFID circulation system (funded through a grant from the Thyne Reid Foundation). The library now has two rooms, with a separate computer lab for students. Its catalogue is online and available through the School's website and it has a wiki-based subject guide, also available through the School's website. Structuring the wiki around typical student tasks such as finding information and writing their assignments has resulted in a doubling of the guide's usage, which suggests that it is now meeting student needs better than it did previously when it focused on resource types. The wiki has demonstrated that it is possible to create subject guides for cash-strapped academic libraries using freely available resources. Its increased usage also demonstrates that focusing the subject guide around key student tasks is more helpful to students than simply focusing on resources. 


\section{Bibliography}

Adelaide Central School of Art. 2015. “ACSA Library Online Resources.” http://acsalibraryonlineresources.wikispaces.com/.

Australian Library and Information Association. 2014. "Future of the Library and Information Science.” Canberra, ACT. https://www.alia.org.au/sites/default/files/ALIALIS-Education-Skills-and-Employment-Trend-Report-2014.pdf.

Bejune, Matthew M. 2007. "Wikis in Libraries.” Information Technology \& Libraries 26 (September): 26-39. doi:Article.

Boateng, Frank, and Yan Quan Liu. 2014. "Web 2.0 Applications’ Usage and Trends in Top US Academic Libraries.” Library Hi Tech 32 (1) (March 11): 120-138. doi:10.1108/LHT-07-2013-0093. http://www.emeraldinsight.com.access.library.unisa.edu.au/doi/full/10.1108/LHT-072013-0093.

Boeninger, Chad. 2011. "Biz Wiki to Be Discontinued: Biz Wiki." http://web.archive.org/web/20110620045305/http://www.library.ohiou.edu/subjects/biz wiki/index.php/Biz_Wiki_to_be_Discontinued.

Castro Gessner, Gabriela, Adam Chandler, and Wendy Sue Wilcox. 2015. “Are You Reaching Your Audience? The Intersection between LibGuide Authors and LibGuide Users.” Edited by Assoc. Prof. Louise Feldmann ,Dr Beth Kayl. Reference Services Review 43 (3) (August 10): 491-508. doi:10.1108/RSR-02-2015-0010. http://www.emeraldinsight.com.access.library.unisa.edu.au/doi/full/10.1108/RSR-022015-0010.

Chua, Alton Y.K., and Dion H Goh. 2010. "A Study of Web 2.0 Applications in Library Websites.” Library \& Information Science Research 32 (3) (July): 203-211. doi:10.1016/j.lisr.2010.01.002. http://www.sciencedirect.com/science/article/pii/S0740818810000307.

Farkas, Meredith. 2007. “Technology in Practice: Subject Guide 2.0.” American Libraries 38 (5): 33. http://www.jstor.org/stable/27771169.

Google. 2015. “Google Analytics.” Accessed August 14. http://www.google.com.au/analytics/.

Hintz, Kimberley, Paula Farrar, Shirin Eshghi, Barbara Sobol, Jo-Anne Naslund, Teresa Lee, Tara Stephens, and Aleha McCauley. 2010. "Letting Students Take the Lead: A UserCentred Approach to Evaluating Subject Guides.” Evidence Based Library and Information Practice.

http://ejournals.library.ualberta.ca/index.php/EBLIP/article/view/8663.

ITHAKA. 2015. “JSTOR.” http://www.jstor.org/.

Jones, Mike, and Deb Verhoeven. 2016. "Treasure Trove: Why Defunding Trove Leaves Australia Poorer.” The Conversation. https://theconversation.com/treasure-trove-whydefunding-trove-leaves-australia-poorer-55217.

Kerrigan, Catherine. 2014. "Targeted Information Literacy for Art Students.” In 2014 ARLIS/ANZ Conference "He Raranga Toi." Auckland.

MoMALearning. 2015. “Glossary of Art Terms.” Accessed August 14. http://www.moma.org/learn/moma_learning/glossary. 
National Library of Australia. 2016a. “About Trove.” Trove. Accessed March 28. http://trove.nla.gov.au/general/about.

—. 2015b. “eResources.” Accessed August 14. http://www.nla.gov.au/app/eresources/.

- 2013. "Home - Trove.” http://trove.nla.gov.au/?q=.

Nguyen, Linh Cuong. 2008. "A Survey of the Application of Web 2.0 in Australasian University Libraries.” Edited by Elke Greifender. Library Hi Tech 26 (4) (November 21): 630-653. doi:10.1108/07378830810920950.

http://www.emeraldinsight.com.access.library.unisa.edu.au/doi/full/10.1108/073788308 10920950.

Norton, Andrew, and Ittima Cherastidtham. 2014. "Mapping Australian Higher Education, 2014-2015.” Carlton, Vic.: Grattan Institute. http://grattan.edu.au/report/mappingaustralian-higher-education-2014-15/.

Ouellelte, Dana. 2011. "Subject Guides in Academic Libraries: A User-Centred Study of Uses and Perceptions.” The Canadian Joumal of Information and Library Science 35 (4): 436-451.

Oxford University Press. 2015. “Oxford Art Online.” http://www.oxfordartonline.com/public/.

Richards, Talia. 2014. “What's Custom Domain Mapping? How Do We Set It Up?” Guide FAQs for Libguides v1. http://guidefaq.com/a.php?qid=55023.

SpringShare. 2013. "LibGuides by Springshare - Content Management For Libraries.” http://springshare.com/libguides/.

Tangient LLC. 2015a. “Wikispaces.” http://www.wikispaces.com/.

. 2015b. “Wiki Classroom.” http://www.wikispaces.com/content/classroom.

. 2015c. “Wiki Campus.” http://www.wikispaces.com/content/private-label/higher-ed.

Tate Gallery. 2015. “Glossary of Art Terms.” Accessed August 14.

http://www.tate.org.uk/learn/online-resources/glossary.

The Australian Academy of the Humanities. 2016. "Critical Research Infrastructure at Risk." http://www.humanities.org.au/News/News/tabid/109/articleType/ArticleView/articleId/1 998/Critical-research-infrastructure-at-risk.aspx.

Tripathi, Manorama, and Sunil Kumar. 2010. “Use of Web 2.0 Tools in Academic Libraries: A Reconnaissance of the International Landscape.” The International Information \& Library Review 42 (3) (September): 195-207. doi:10.1016/j.iilr.2010.07.005. http://www.sciencedirect.com/science/article/pii/S1057231710000445.

Wikispaces. 2014. “Adding a Custom Domain Name for Your Site.” Support Center. http://helpcenter.wikispaces.com/customer/portal/articles/1964486-adding-a-customdomain-name-for-your-site.

Woody, Lorelei. 2015. “CampusGuides: A Solution for the Hospital Library.” Journal of Hospital Librarianship 15 (1) (February 6): 1-12. doi:10.1080/15323269.2015.982007. http://www.tandfonline.com.access.library.unisa.edu.au/doi/abs/10.1080/15323269.2015 .982007\#.Vka_4uLmmao.

Wordofa, Kebede H. 2014. "Adoption of Web 2.0 in Academic Libraries of Top African Universities.” Electronic Library, The 32 (2): 262-277. doi:10.1108/EL-07-2012-0077. http://www.emeraldinsight.com/journals.htm?issn=0264$0473 \&$ volume $=32$ \&issue $=2 \&$ articleid $=17110470 \&$ show $=$ html . 
Yang, Sharon Q. 2009. “Subject Guide 2.0: A Dream or Reality?” Journal of Library and Information Science. http://jlis.glis.ntnu.edu.tw/ojs/index.php/jlis/article/view/522. 